\title{
Obesity dysregulates fasting-induced changes in glucagon secretion
}

\author{
Jennifer H Stern ${ }^{1, \dagger}$, Gordon I Smith², Shiuwei Chen' ${ }^{1}$, Roger H Unger ${ }^{1}$, Samuel Klein ${ }^{2}$ and Philipp E Scherer \\ 1Touchstone Diabetes Center, Department of Internal Medicine, The University of Texas Southwestern Medical Center, Dallas, Texas, USA \\ ${ }^{2}$ Center for Human Nutrition, Washington University School of Medicine, Saint Louis, Missouri, USA
}

Correspondence should be addressed to P E Scherer: philipp.scherer@utsouthwestern.edu

$+\mathrm{J} H$ Stern is now at Division of Endocrinology, University of Arizona, College of Medicine, Tucson, Arizona, USA)

\begin{abstract}
Hyperglucagonemia, a hallmark in obesity and insulin resistance promotes hepatic glucose output, exacerbating hyperglycemia and thus predisposing to the development type 2 diabetes. As such, glucagon signaling is a key target for new therapeutics to manage insulin resistance. We evaluated glucagon homeostasis in lean and obese mice and people. In lean mice, fasting for $24 \mathrm{~h}$ caused a rise in glucagon. In contrast, a decrease in serum glucagon compared to baseline was observed in diet-induced obese mice between 8 and $24 \mathrm{~h}$ of fasting. Fasting decreased serum insulin in both lean and obese mice. Accordingly, the glucagon:insulin ratio was unaffected by fasting in obese mice but increased in lean mice. Re-feeding $(2 \mathrm{~h}$ ) restored hyperglucagonemia in obese mice. Pancreatic perfusion studies confirm that fasting ( $16 \mathrm{~h}$ ) decreases pancreatic glucagon secretion in obese mice. Consistent with our findings in the mouse, a mixed meal increased serum glucagon and insulin concentrations in obese humans, both of which decreased with time after a meal. Consequently, fasting and re-feeding less robustly affected glucagon:insulin ratios in obese compared to lean participants. The glucoregulatory disturbance in obesity may be driven by inappropriate regulation of glucagon by fasting and a static glucagon:insulin ratio.
\end{abstract}

\section{Introduction}

Obesity-associated insulin resistance (IR) is characterized by both hyperinsulinemia and hyperglucagonemia and is a key risk factor for the development of type 2 diabetes (T2DM). Although abnormalities in insulin action have been a major focus of metabolic research in obesity, glucagon is also an important regulator of glycemic control. In fact, Orci and Unger's 'bihormonal hypothesis' (1975) (Unger \& Orci 1975) prompted decades of work that created abundant evidence identifying basal and postprandial hyperglucagonemia as drivers of the hyperglycemia observed in people with T2DM
(Baron et al. 1987, Shah et al. 2000, Lee et al. 2014). Plasma glucagon is elevated in people who are obese and insulin resistant (Baron et al. 1987, Shah et al. 2000), and meal-induced suppression of glucagon is blunted in people with IR (Muller et al. 1970, Unger et al. 1972, Larsson \& Ahren 2000, Knop et al. 2007, Bagger et al. 2014). In fact, some studies show that people with IR respond to a meal with an increase in glucagon (Muller et al. 1970, Knop et al. 2007).

Suppression of glucagon signaling improves glycemic control in people with IR (Kazda et al. 2016, 
Vajda et al. 2017, Kostic et al. 2018), in hyperinsulinemic/ insulin-resistant mice (Lee et al. 2014), and in insulindeficient type 1 diabetic mice (Lee et al. 2011, RiveroGutierrez et al. 2018). Incretin therapies, such as glucagon-like peptide-1 receptor agonists and dipeptidyl peptidase- 4 inhibitors, decrease glucagon secretion and reduce blood glucose in people with IR (Nauck et al. 1993, Hare et al. 2010). The liver is the main site of glucagon action and plays a critical role in the regulation of hepatic glycogenolysis, gluconeogenesis and fatty acid oxidation. Since glucagon and insulin have opposite hepatic metabolic effects, the relative glucagon to insulin signal provides a better understanding of metabolic regulation than measures of either glucagon or insulin alone (Glinsmann \& Mortimore 1968, Mackrell \& Sokal 1969). Normally, the glucagon:insulin ratio increases during fasting, leading to a predominant glucagon signal, which increases hepatic intracellular concentrations of the second messenger cyclic adenosine monophosphate (cAMP) and downstream PKA and CREB signaling pathways, increasing hepatic glucose output (Seitz et al. 1977, Mutel et al. 2011). In turn, re-feeding decreases the glucagon:insulin ratio, resulting in dominant insulin signaling that decreases cAMP via activation of phosphodiesterase and reduces hepatic glucose output (Benelli et al. 1986). Insulin also acts in a paracrine fashion at the alpha-cell to decrease glucagon secretion (Maruyama et al. 1984, Kawamori et al. 2009). Accordingly, identifying the effect of fasting and feeding on glucagon, insulin, and the glucagon:insulin ratio (Unger 1971, Parrilla et al. 1974) in obesity is important for understanding the hormonal regulation of hepatic metabolic response and the metabolic alterations associated with IR.

The purpose of the present study was to test the hypothesis that obesity dysregulates the normal hormonal glucoregulatory response to fasting and re-feeding. Accordingly, we evaluated circulating glucagon, insulin, and the glucagon:insulin ratio in healthy lean and insulin-resistant obese mice and in people who were lean and metabolically healthy or obese and insulin-resistant during fed and fasted conditions.

\section{Materials and methods}

\section{Animal studies}

All studies were conducted in male wildtype C57BL/6J mice bred in-house at UT Southwestern Medical Center. Mice were maintained on a 12-h light/12-h darkness cycle and housed 3-5 mice per cage at least 1 week prior to the study, at which time animals were individually housed. Mice were housed with sani-chip bedding (7090 Teklad). We conducted studies on lean chow fed mice (2016 Teklad Global 16\% Protein Rodent Diet, 12\% kcal from fat) and diet-induced obese mice (Bio Serv S 1850, 60\% kcal from fat) at 18-20 weeks of age. Studies in diet-induced obese mice were conducted after 12-14 weeks on a high-fat diet. Mice fed the high-fat diet weighing less than $37 \mathrm{~g}$ were excluded from the studies. With the exception of fasting studies, mice had ad libitum access to food and water. All studies were approved by The University of Texas Southwestern Institutional Animal Care and Use Committee.

\section{Fasting duration studies}

To achieve fasting durations of $24,16,8$, or $4 \mathrm{~h}$, fasting was initiated at $10: 00 \mathrm{~h}, 18: 00 \mathrm{~h}, 02: 00 \mathrm{~h}$ or $06: 00 \mathrm{~h}$, respectively. Mice were killed at $10: 00 \mathrm{~h}$ by decapitation after open-drop exposure to isoflurane anesthesia. Trunk blood was immediately collected and allowed to clot for $30 \mathrm{~min}$ prior to centrifugation at $3000 \mathrm{~g}$ for $30 \mathrm{~min}$. Serum was collected, aliquoted, and immediately frozen at $-80^{\circ} \mathrm{C}$.

\section{Fed, fast, re-fed studies}

Blood was collected from the tail vein of each mouse at three times over $26 \mathrm{~h}$. Fed blood was collected at 10:00 h in mice with ad libitum food access. Food was removed at 18:00 $\mathrm{h}$ and at 10:00 $\mathrm{h}$ the following day we collected blood from $16 \mathrm{~h}$ fasted mice. Immediately following blood collection at 10:00 h, mice were offered chow or high-fat diet for $2 \mathrm{~h}$ prior to a final blood collection.

\section{Glucagon and somatostatin secretion in perfused mouse pancreas}

To directly measure the effect of insulin on glucagon and somatostatin secretion, mouse pancreata were perfused as previously described (Wargent 2009). After an equilibrium period of $15 \mathrm{~min}$ at $5.5 \mathrm{mM}$ glucose, the perfusion solution was switched to $2 \mathrm{mM}$ glucose and the concentration of insulin was gradually increased from $0(0-15 \mathrm{~min})$ to mimic concentrations seen in a lean fasted mouse $(8.605 \mathrm{pM}$; 15-25 min), lean-fed mouse (51.63 pM; $25-35 \mathrm{~min})$, obese hyperinsulinemic mouse (860.5 pM; 35-45 min), and a supraphysiological concentration (8605 pM; 45-55 min). Perfusate was collected continuously with samples pooled at 5 -min intervals before being frozen at $-80^{\circ} \mathrm{C}$ until further analysis. 


\section{Human studies}

\section{Subjects}

Twenty-six men and women who were lean and metabolically healthy ( $n=9$, five women, $36.3 \pm 9.2$ years) or obese and metabolically unhealthy ( $n=17,12$ women, $44.0 \pm 8.0$ years) participated in this study, which was approved by the Human Research Protection Office at Washington University School of Medicine in St. Louis, MO (ClinicalTrials.gov number NCT02706262). Written, informed consent was obtained from all subjects before their participation. All subjects completed a comprehensive medical evaluation at screening, including a history and physical examination, standard blood tests, hemoglobin A1C (HbA1c), an oral glucose tolerance test (OGTT) and magnetic resonance imaging (MRI) (3-T MAGNETOM Vida; Siemens) to determine intrahepatic triglyceride (IHTG) content. The inclusion criteria for the metabolically healthy lean group were BMI $18.5-24.9 \mathrm{~kg} / \mathrm{m}^{2}$; IHTG content $\leq 5 \%$, serum triglyceride $<150 \mathrm{mg} / \mathrm{dL}$, fasting plasma glucose $<100 \mathrm{mg} / \mathrm{dL}, 2$-h OGTT plasma glucose $\leq 140 \mathrm{mg} / \mathrm{dL}$, and HbA1c $\leq 5.6$. The inclusion criteria for the metabolically unhealthy obese group were BMI $30-49.9 \mathrm{~kg} / \mathrm{m}^{2}$; IHTG content $>5.6 \%$ and $\mathrm{HbA} 1 \mathrm{c} \geq 5.7 \%$ or fasting plasma glucose $\geq 100 \mathrm{mg} / \mathrm{dL}$ or 2 -h OGTT plasma glucose $\geq 140 \mathrm{mg} / \mathrm{dL}$. No subject had a history of diabetes, took medications known to affect the study outcomes, or consumed excessive amounts of alcohol (>21 units of alcohol/week for men and $>14$ units for women).

\section{Mixed meal response}

Subjects were instructed to avoid caffeine and alcohol for at least $24 \mathrm{~h}$ and abstain from exercise 3 days prior to admission to the Clinical and Translational Research Unit (CTRU) at Washington University School of Medicine. Subjects were admitted to the CTRU at 18:00h the day before the mixed meal study and consumed a standard dinner at 19:00h. At 06:30h the following morning, after subjects fasted for $11 \mathrm{~h}$ overnight, a catheter was inserted into an antecubital vein for serial blood sampling. At 07:00h a standard meal, containing one-third of estimated daily energy requirements (Mifflin et al. 1990) and 50\% of energy as carbohydrate, 35\% as fat, and $15 \%$ as protein, was provided and ingested over $30 \mathrm{~min}$. Blood samples were obtained immediately before and $0.5,1$, $1.5,2,3,4,5$ and $6 \mathrm{~h}$ after initiating meal ingestion.

\section{Sample analysis}

\section{Serum, perfusate, and plasma assays}

Serum (mouse), pancreatic perfusate, and plasma (human) glucagon were analyzed by enzyme-linked immunosorbent assay (ELISA; Cat. \# 10-1271-01, Mercodia, Uppsala, Sweden). Serum glucose from mouse studies was analyzed by colorimetric assay (Cat. \# G7519, Pointe Scientific Inc., Canton, MI, USA). Serum insulin from mouse studies was analyzed by ELISA (Cat. \# 80-INSMSU-E10, Alpco). Perfusate somatostatin concentration was measured by ELISA (Cat. \# EK-060-03, Phoenix Pharmaceuticals, Burlingame, CA, USA). Plasma glucose in human samples was determined by using an automated glucose analyzer (Yellow Spring Instruments Co, Yellow Springs, OH, USA). Plasma insulin in human samples was measured by using electrochemiluminescence technology (Elecsys 2010, Roche Diagnostics).

\section{Liver analyses}

Prior to all analyses, whole mouse livers frozen at $-80^{\circ} \mathrm{C}$ were powdered with a liquid nitrogen cooled mortar and pestle to ensure a homogenous sample.

To determine hepatic cAMP content, an aliquot of powdered liver was weighed and immediately sonicated in a known volume of $0.1 \mathrm{M} \mathrm{HCl}$. The homogenate was then centrifuged at $5000 \mathrm{~g}$. The supernatant was removed and assayed for cAMP by enzyme-linked immunosorbent assay (ELISA; Cat \# ADI-900-066, Enzo Life Sciences, Farmingdale, NY, USA) and expressed per gram of tissue.

We analyzed liver glycogen content using a previously described colorimetric assay (Lo et al. 1970). Briefly, 10-15 mg powdered liver was weighed before being boiled in $30 \% \mathrm{KOH}$ saturated with $\mathrm{NA}_{2} \mathrm{SO}_{4}$ for $30 \mathrm{~min}$ while shaking. Glycogen was then precipitated with $95 \%$ ethanol and pelleted by centrifugation at $3000 \boldsymbol{g}$ for $30 \mathrm{~min}$. The supernatants were aspirated and glycogen pellets were dissolved in distilled $\mathrm{H}_{2} \mathrm{O}$. Phenol (5\%) was added to the samples followed by a rapid stream of $\mathrm{H}_{2} \mathrm{SO}_{4}$. Samples were then incubated at $30^{\circ} \mathrm{C}$ for $20 \mathrm{~min}$ and absorbance was read at $490 \mathrm{~nm}$. Glycogen content was expressed per gram of tissue.

We isolated RNA from powdered liver samples using TRIzol $^{\text {TM }}$ Reagent (Thermo Fisher Scientific). Phenol was eliminated using the water saturated butanol and ether method of Krebs et al. (2009). Reverse transcription was performed using Verso cDNA synthesis kit (Thermo Scientific, Inc.), and qPCR performed using PowerUp ${ }^{\mathrm{TM}}$ SYBR $^{\text {TM }}$ Green Master Mix on the Applied Biosystems QuantStudio 6 Flex Real-Time PCR System (Applied Biosystems $\left.{ }^{\mathrm{TM}}\right)$. We used LinReg PCR analysis software to determine the efficiency of amplification from raw CT data (Ramakers et al. 2003). ACT $\beta$ served as the reference gene for calculating fold change in gene expression using the efficiency- $\Delta \Delta$ Ct method (Livak \& Schmittgen 2001). 
Table 1 List of primer sequences for RT-PCR.

\begin{tabular}{lll}
\hline Gene & Forward primer $\left(5^{\prime}-3^{\prime}\right)$ \\
\cline { 1 - 1 } Mouse Actb & & TCGGTGACATCAAAGAGAAG \\
Mouse G6pc & CGACTCGCTATCTCCAAGTGA \\
Mouse Pepck & CTGCATAACGGTCTGGACTTC \\
Mouse Cpt1a & CTCCGCCTGAGCCATGAAG \\
Mouse Tat & TGCTGGATGTTCGCGTCAATA \\
\hline
\end{tabular}

\begin{tabular}{l} 
Reverse primer $\left(5^{\prime}-3^{\prime}\right)$ \\
\hline GATGCCACAGGATTCCATA \\
GTTGAACCAGTCTCCGACCA \\
CAGCAACTGCCCGTACTCC \\
CACCAGTGATGATGCCATTCT \\
CGGCTTCACCTTCATGTTGTC \\
\hline
\end{tabular}

$\begin{array}{r}\hline \text { Gene ID } \\ \hline 11461 \\ 14377 \\ 18534 \\ 12894 \\ 234724 \\ \hline\end{array}$

Mouse primer sequences for real-time PCR are presented in Table 1.

We analyzed hepatic protein expression of phosphorylated and total cyclic AMP response elementbinding protein (CREB), phosphorylated activating transcription factor-1 (ATF-1), and phosphorylated and total AKT by Western blot. To prepare lysates, we ground the livers using a liquid nitrogen cooled mortar and pestle, then homogenized the ground liver in RIPA buffer (Santa Cruz Biotechnology) with protease and phosphatase inhibitors (Thermo Scientific). Total protein was quantified via BCA protein assay (Thermo Scientific). Forty micrograms protein per sample were loaded and separated on a $4-12 \%$ Bis Tris gel (Invitrogen) and transferred onto a nitrocellulose membrane $(0.2 \mu \mathrm{m}$ pore size). Membranes were blocked for $1 \mathrm{~h}$ at room temperature in a blocking solution (Tris-buffered saline with $0.5 \%$ Tween 20 (TBST) with $5 \% \mathrm{w} / \mathrm{v}$ nonfat dry milk), and then incubated overnight at $4^{\circ} \mathrm{C}$ with primary antibodies diluted 1:1000 in blocking solution. The following day, membranes were washed three times for $5 \mathrm{~min}$ with TBST, then incubated with a secondary antibody (anti-rabbit IgG, HRP-linked antibody, Cell Signaling \#7074) diluted 1:2000 in blocking solution for $1 \mathrm{~h}$ at room temperature. Signals were visualized using enhanced chemiluminescence reagents (Invitrogen) on the ChemiDoc imaging system (Bio-Rad) and band intensities were quantified using Image Lab software version 6.0.1 (Bio-Rad). Phosphorylated and total protein content were expressed relative to the within-gel loading control protein, Histone H3. All antibodies were

Table 2 Characteristics of the study participants.

\begin{tabular}{|c|c|c|}
\hline & Lean $(n=9)$ & Obese $(n=17)$ \\
\hline $\mathrm{BMI}$ & $23.0 \pm 1.7 a$ & $39.8 \pm 5.2^{b}$ \\
\hline IHTG content (\%) & $1.5 \pm 0.4^{a}$ & $15.9 \pm 9.8^{b}$ \\
\hline \multicolumn{3}{|c|}{ OGTT glucose (mg/dL) } \\
\hline Time 0 min & $85 \pm 4^{a}$ & $102 \pm 11 b$ \\
\hline Time $120 \mathrm{~min}$ & $96 \pm 21^{a}$ & $163 \pm 34^{b}$ \\
\hline $\mathrm{HbA} 1 \mathrm{c}(\%)$ & $5.0 \pm 0.4^{a}$ & $5.8 \pm 0.7^{b}$ \\
\hline
\end{tabular}

Values are means \pm S.D.

a,bSuperscript letters that differ indicate significant differences between groups, $P<0.05$; student's $t$-test.

IHTG, intrahepatic triglyceride; OGTT, oral glucose tolerance test.

https://joe.bioscientifica.com

https://doi.org/10.1530/JOE-19-0201
(C) 2019 Society for Endocrinology Published by Bioscientifica Ltd. Printed in Great Britain purchased from Cell Signaling and have been previously verified with appropriate controls (Jewell et al. 2019, Townsend et al. 2019). We detected total CREB with antiCREB antibody (\# 9197) and phosphorylated CREB levels with anti-phospho-CREB antibody which detects CREB phosphorylated at serine 133 and the phosphorylated form of the CREB-related protein, cyclic AMP-dependent transcription factor ATF-1 (\# 9198). We detected total AKT, phosphorylated AKT (Ser473) levels, and Histone H3 with antibody numbers 9272, 9271, and 12648 respectively (Cell Signaling).

\section{Statistical analyses}

Statistical analyses were performed in SAS Enterprise Guide 7.1 (SAS Institute Inc.). To assess the effect of fasting duration $(0,4,8,16$ and $24 \mathrm{~h})$ within diet group (lean and obese) on all dependent variables in our animal studies, we used the mixed model procedure. When statistically significant interactions were found, Tukey's adjustment for multiple comparisons was used to identify significant mean differences. Independent Student's $t$-test assessed differences between lean and obese groups within each timepoint. Data from fasting-re-feeding studies and perfusion studies were analyzed using repeated-measures ANOVA including timepoint and group in the analyses and difference between means assessed by post hoc analysis using the Tukey-Kramer correction for multiple comparisons. Pearson's correlations assessed the strength of associations between hepatic cAMP levels and serum glucagon or insulin. Student's $t$-test was used to compare basic characteristics of participants between groups. Twoway ANOVA with time (before and 0.5, 1, 1.5, 2, 3, 4, 5 and 6 after mixed meal ingestion) as the within-subject factor and group (lean and obese) as between-subject factor was used to evaluate the effect of mixed meal ingestion on plasma glucose, insulin and glucagon concentration. When statistically significant interactions were found, Tukey-Kramer's post hoc procedure was used to identify significant mean differences. Independent variables were identified as classification variables in all models. Raw data were plotted in Graphpad PRISM®, version 8 for 
Windows (GraphPad Software). All data are presented as mean \pm standard error.

\section{Results}

\section{Glucoregulatory hormone status}

In the fed state, diet-induced obese mice were hyperglucagonemic compared to lean mice $(P<0.05$; Fig. 1A). In lean mice, a 24-h fast increased serum glucagon significantly $(P<0.05$; Fig. $1 \mathrm{~A})$. In contrast, obese mice responded to fasting with a significant decrease in serum glucagon after $8 \mathrm{~h}$ of fasting and glucagon remained low after 16 and $24 \mathrm{~h}$ of fasting $(P<0.05$; Fig. $1 \mathrm{~A})$. In obese mice, both glucagon and insulin decrease with fasting $(P<0.05$; Fig. $1 \mathrm{~A}$ and B). Accordingly, the glucagon:insulin ratio increases with fasting in the lean mouse, but not in obese mice $(P<0.05$; Fig. $1 C)$. Serum glucose decreases significantly by $16 \mathrm{~h}$ of fasting in lean mice. Yet, in line with an insulin-resistant state, the fasting-induced decrease in serum glucose is blunted in obese mice $(P<0.05$; Fig. 1D). As expected, the glucose:insulin ratio increases with fasting in both groups of mice. However, this ratio is lower in obese mice $(P<0.05$; Fig. $1 \mathrm{E})$.

Having demonstrated that fasting elicits a decrease in serum glucagon in obese mice, we set out to examine the effects of re-feeding after a 16-h fast. We confirmed that $16 \mathrm{~h}$ of fasting significantly decreases both serum glucagon and insulin in the obese mouse $(P<0.05$; Fig. $2 \mathrm{~A}$ and $\mathrm{B})$ leading to a non-responsive glucagon:insulin ratio (Fig. 2C). Lean mice responded to the fast with a slight, nonsignificant, increase in glucagon and decrease in insulin, yielding a significant increase in the glucagon:insulin ratio $(P<0.05$; Fig. $2 \mathrm{~A}, \mathrm{~B}$ and $\mathrm{C})$. Two hours of re-feeding restored the hyperglucagonemic and hyperinsulinemic state in the obese mouse $(P<0.05$ compared to $16 \mathrm{~h}$ fasted), yielding a static glucagon:insulin ratio in obese mice throughout the study. Interestingly, re-feeding also increased serum glucagon in the lean mice $(P<0.05)$, but to a lesser extent. As expected, serum glucose decreased with fasting and increased with feeding in lean mice, while no significant change was observed after a $16 \mathrm{~h}$ fast in the obese group. Re-feeding caused a mild, but significant decrease in serum glucose in obese mice (Fig. 2D).

\section{Downstream targets of glucagon}

We next explored if the observed fasting-induced changes in glucagon and the glucagon:insulin ratio affected downstream targets of glucagon signaling. We measured changes in cAMP content in livers from mice in our fasting duration studies (Fig. 3A). In lean mice, hepatic cAMP increased as fasting duration increased to $24 \mathrm{~h}(P<0.05)$. In contrast, livers from obese mice show no change in cAMP in response to a fast. Since glucagon and insulin affect cAMP production and breakdown, respectively, we correlated liver cAMP with serum glucagon and insulin (Fig. 4). As expected, in lean mice hepatic cAMP levels correlate positively with serum glucagon $(P=0.004, r=0.43)$ and negatively with serum insulin $(P=0.006, r=-0.42)$. Hepatic cAMP does not correlate with glucagon or insulin in diet-induced obese mice, suggesting that hormoneinduced changes in hepatic cAMP are dysregulated.

Glucagon-stimulated glycogenolysis is dependent on a rise in cAMP. Thus, we examined liver glycogen content in livers from these mice. In the fed state, liver glycogen did not differ between lean and obese mice. However, obese mice show an attenuation of fastinginduced liver glycogen loss (Fig. 3B). By increasing cAMP, glucagon stimulates the phosphorylation of CREB and the cAMP-regulated enhancer-binding protein, activating transcription factor-1 (ATF-1), which is more responsive to cAMP (Rehfuss et al. 1991, Sun et al. 1996). In line with our observation that re-feeding in obese mice restores
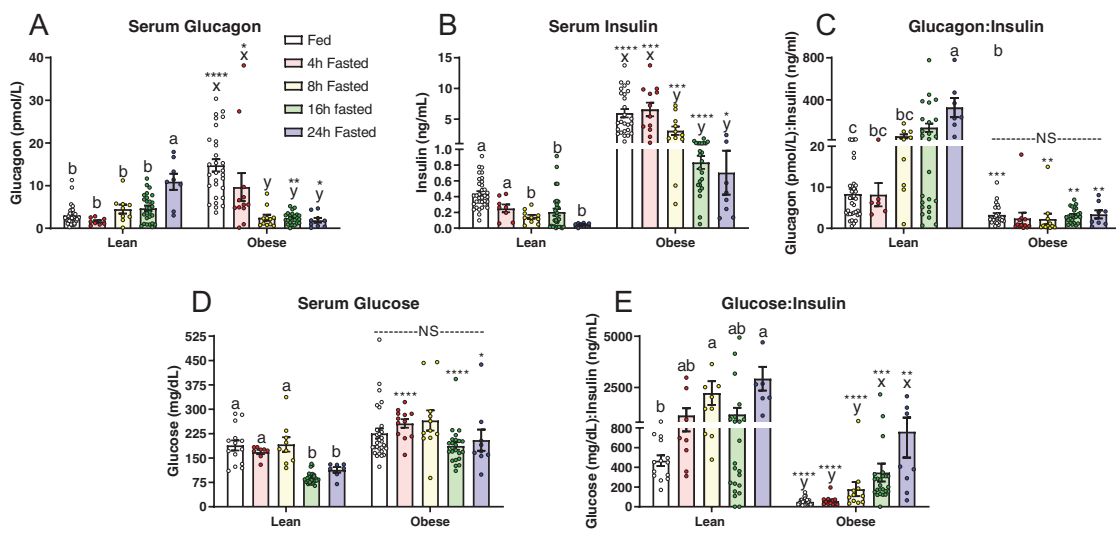

Figure 1

Serum (A), glucagon, (B) insulin, (C) glucagon: insulin ratio, (D) glucose, and (E) glucose: insulin ratio in lean (fed: $n=33$ for glucagon and insulin, $n=14$ for glucose), $4 \mathrm{~h}: n=8,8 \mathrm{~h}: n=9,16 \mathrm{~h}$ : $n=27$, and $24 \mathrm{~h}$ fasted: $n=8$ ) and diet-induced obese (fed: $n=29,4$ h: $n=12,8$ h: $n=11,16$ h: $n=24$, and $24 \mathrm{~h}$ fasted: $n=9$ ) mice fed ad libitum, and fasted for $4,8,16$, and $24 \mathrm{~h}$. Letters that differ indicate differences within group (a,b,cLean, $x, y, z$ Obese),$P<0.05 ; * \star \star * *, * * *, * *, *$ indicate when obese differs from lean within timepoint, $\star \star \star * * P \leq 0.0001, * * * P<0.001, * * P<0.01, * P<0.05$. Bars indicate means \pm S.E.M. 

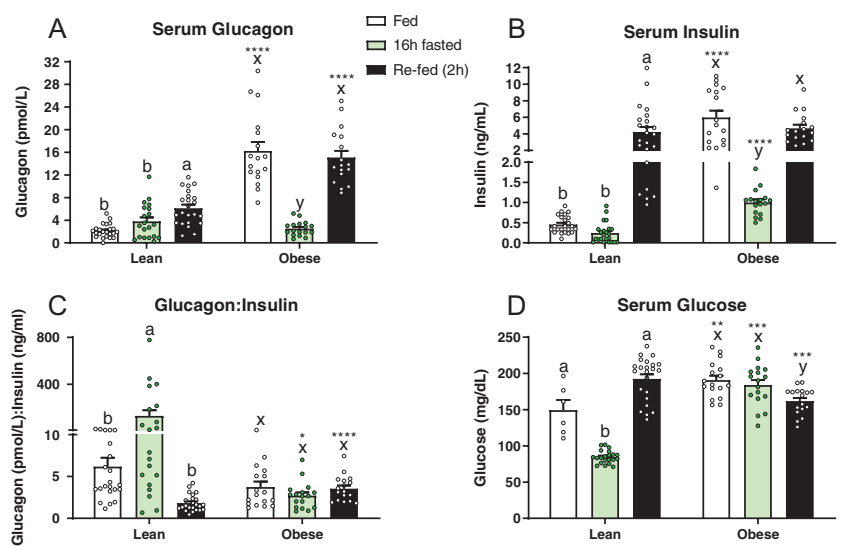

Figure 2

Serum (A), glucagon, (B) insulin, (C) glucagon: insulin ratio, and (D) glucose in lean ( $n=17$ for insulin and glucagon, $n=6$ for glucose) and diet-induced obese ( $n=23$ for all) mice fed ad libitum, fasted for $16 \mathrm{~h}$, and re-fed for $2 \mathrm{~h}$. Letters that differ indicate differences within group ( $a, b, c$ Lean, $x, y, z$ Obese), $P<0.05 ; * * * *, * * *, * *, *$ indicate when obese differs from lean within timepoint, $* * * * P \leq 0.0001, * * * P<0.001, * * P<0.01, * P<0.05$. Bars indicate means \pm S.E.M.

hyperglucagonemia, $2 \mathrm{~h}$ of re-feeding after a $16 \mathrm{~h}$ fast failed to significantly decrease levels of phosphorylated ATF-1 in the livers of obese mice. In contrast, we observed a robust decrease in phosphorylated ATF-1 in the livers of re-fed lean mice $(P<0.0001$, Fig. $5 \mathrm{~A}$ and $\mathrm{B})$. Re-feeding, however, did not affect levels of phosphorylated CREB in either lean or obese mice (Fig. 5A and C). Re-feeding after an overnight fast in mice normally stimulates an increase in the phosphorylation of AKT at the liver via downstream insulin signaling (Lu et al. 2012). Consistent with a robust rise in insulin with re-feeding, the phosphorylation of hepatic AKT was elevated in both lean and obese mice in response to re-feeding $(P<0.05$, Fig. 5D and E).

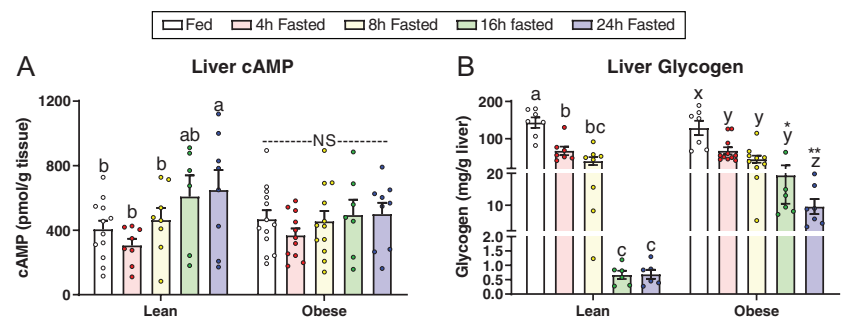

Figure 3

Liver (A) CAMP in lean (fed: $n=12,4 \mathrm{~h}: n=8,8 \mathrm{~h}: n=8,16 \mathrm{~h}: n=6,24 \mathrm{~h}$ fasted: $n=8$ ) and diet-induced obese (fed: $n=13,4 \mathrm{~h}: n=11,8 \mathrm{~h}: n=12$, $16 \mathrm{~h}: n=7,24 \mathrm{~h}$ fasted: $n=9$ ) mice and (B) glycogen in lean (fed: $n=7,4 \mathrm{~h}$ : $n=7,8 \mathrm{~h}: n=8,16 \mathrm{~h}: n=6,24 \mathrm{~h}$ fasted: $n=6$ ) and diet-induced obese (fed: $n=7,4 \mathrm{~h}: n=11,8 \mathrm{~h}: n=10,16 \mathrm{~h}: n=6,24 \mathrm{~h}$ fasted: $n=7$ mice) mice fed $a d$ libitum, or fasted for $4,8,16$, or $24 \mathrm{~h}$. Letters that differ indicate differences within group (a,b,cLean, $x, y, z$ Obese), $P<0.05$; **, * indicates when obese differs from lean within timepoint, $* \star P<0.01, * P<0.05$. Bars indicate means \pm S.E.M.
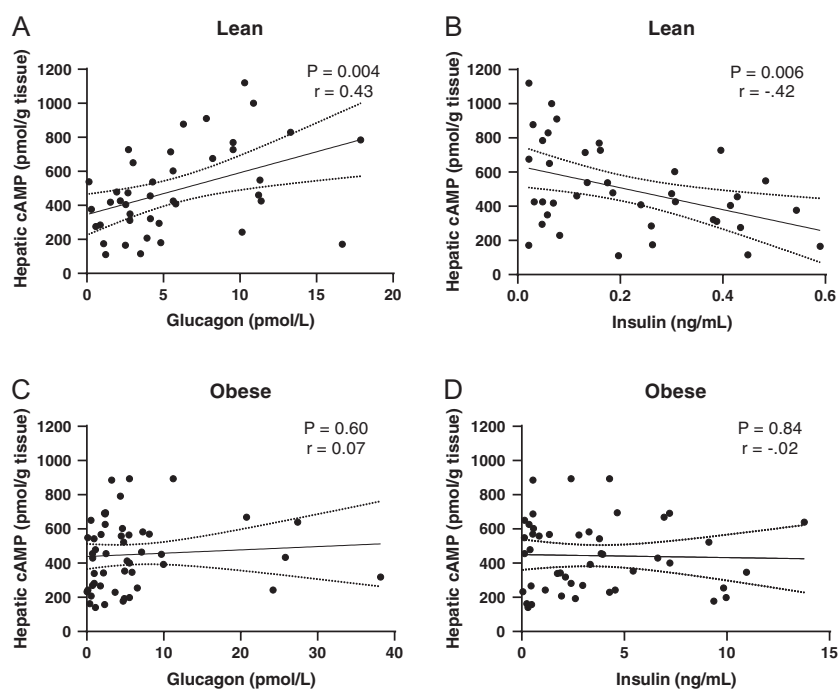

\section{Figure 4}

Pearson's correlation (95\% confidence interval) between (A and C) serum glucagon and hepatic CAMP and (B and D) serum insulin and hepatic cAMP in lean $(n=41)$ and diet-induced obese mice $(n=50)$.

Because glucagon regulates the expression of genes involved in gluconeogenesis and fatty acid oxidation by affecting cAMP, we tested the effects of fasting on cAMP target genes in the liver (Zhang et al. 2005). In lean mice, fasting significantly increased mRNA expression of phosphoenolpyruvate carboxykinase (Pepck), glucose 6-phosphatase $(\mathrm{G} 6 \mathrm{Pc})$, tyrosine aminotransferase (Tat) and carnitine palmitoyl transferase-1a $(C p t 1 a)$, with the most robust increase occurring after $16 \mathrm{~h}$ of fasting (Fig. $6, P<0.05$ ). In contrast, fasting in obese mice had minimal to no effect on gene expression, regardless of fasting duration (Fig. 6).

\section{Pancreatic insulin sensitivity}

To establish that the hyperglucagonemia in obesity and the observed decrease in glucagon in the fasted state are due to changes in pancreatic glucagon secretion, we perfused the pancreas of lean and obese mice (fed vs 16-h fasted) with low glucose $(2 \mathrm{mM})$ and increasing concentrations of insulin. We observed that, prior to perfusing insulin, decreasing perfusate glucose concentration from $5.5 \mathrm{mM}$ (equilibrium period) to $2 \mathrm{mM}$ increased glucagon secretion in lean, but not obese mice. Obesity increased pancreatic glucagon release relative to that seen in lean mice (Fig. $7 \mathrm{~A}, P<0.05)$. We further observed that pancreata of fasted obese mice release less glucagon than those of fed obese mice $(P<0.05)$. Incremental increases in perfusate insulin concentration evoked an equally robust decrease in glucagon secretion in all groups of mice (Fig. 7B). Somatostatin release was higher in lean than in obese mice 

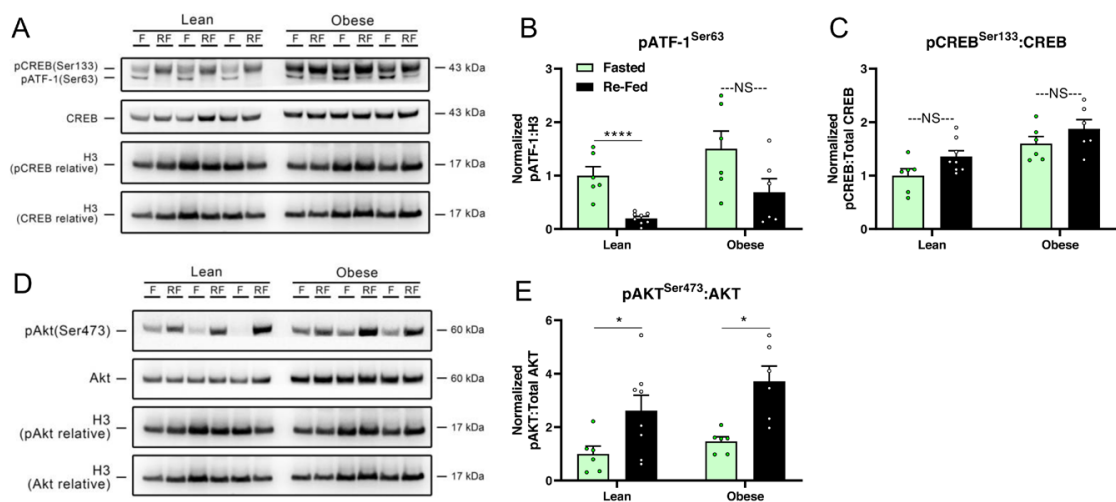

and fasting of obese mice caused a rise in somatostatin (Fig. 7C). Again, insulin lead to a decrease in somatostatin (Fig. 7D).

\section{Basal and postprandial plasma glucagon and insulin in people who are lean and people with obesity and IR}

Having demonstrated that fasting in the obese mouse elicits a decrease in serum glucagon, we set out to examine the effects of fasting and re-feeding in people who were lean and metabolically healthy or obese and metabolically unhealthy (Table 2 ). Basal plasma glucagon concentration obtained after subjects fasted for $12 \mathrm{~h}$ overnight was greater in people who were obese than those who were lean $(P<0.05$, Fig. 8A). Mixed meal consumption caused a greater increase in plasma glucagon and insulin in the obese than in the lean group (Fig. 8A and B). Basal plasma glucagon:insulin ratio was greater in the lean than the obese group (Fig. 8C). Plasma glucagon:insulin ratio decreased to a similar value in both lean and obese subjects from 30 to $90 \mathrm{~min}$ after subjects consumed the mixed meal, and subsequently increased to basal values in both groups. However, the increase in this ratio was more rapid in the lean group (Fig. 8C). Basal plasma glucose concentrations and the postprandial rise in plasma glucose were greater in the obese than lean group $(P<0.05$, Fig. 8D). As we observed in our mouse model, both the basal and postprandial plasma glucose:insulin ratio was lower in the obese than lean group (Fig. 8E), indicative of impaired insulin sensitivity (Legro et al. 1998, GuerreroRomero \& Rodriguez-Moran 2001, Vuguin et al. 2001).

\section{Discussion}

Here we report that extended fasting in the obese mouse decreases $\alpha$-cell glucagon secretion. Contrary to the canonical fasting-induced rise in glucagon, obese mice respond to an extended fast with a robust decrease in serum glucagon. In fact, $8 \mathrm{~h}$ of fasting caused a greater decrease in serum glucagon than serum insulin concentrations. Accordingly, while the glucagon:insulin ratio increases with fasting in lean mice, this ratio does not change with fasting in obese mice.

Glucagon was significantly elevated after $24 \mathrm{~h}$ of fasting in lean mice. Yet, an $8-24 \mathrm{~h}$ fast in obese mice induced a robust decrease in serum glucagon. Singh et al. set out to examine the role of somatostatin receptor subtype- 2 on glucagon secretion in fed and overnight

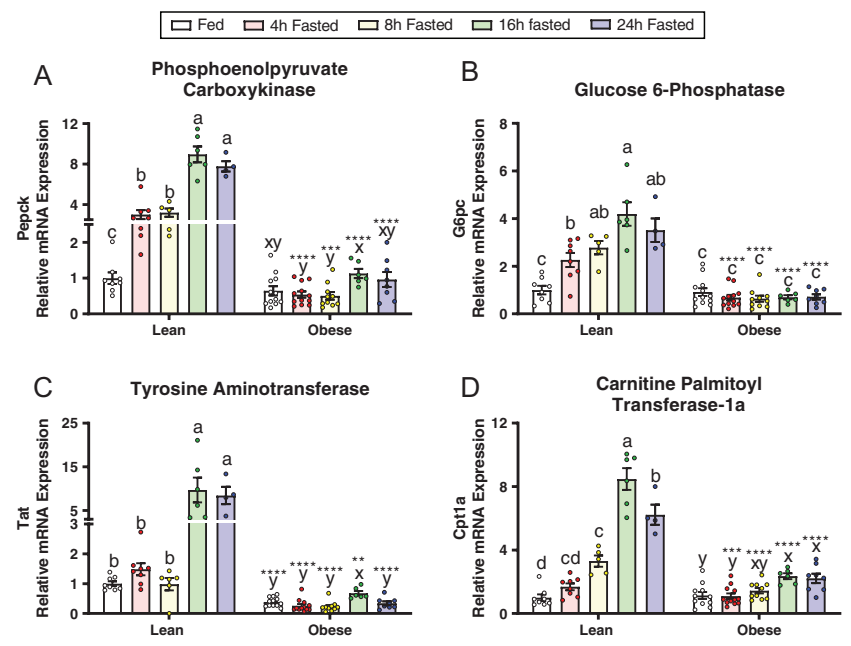

\section{Figure 6}

Relative mRNA expression of glucagon-responsive genes, (A) phosphoenolpyruvate carboxykinase (Pepck), (B) glucose 6-phosphatase $(G 6 p c),(C)$ tyrosine aminotransferase (Tat), and (D) carnitine palmitoyl transferase-1a (Cpt1a) in lean (fed: $n=8,4 \mathrm{~h}: n=8,8 \mathrm{~h}: n=5,16 \mathrm{~h}: n=6$, $24 \mathrm{~h}$ fasted: $n=4$ ) and diet-induced obese (fed: $n=12,4 \mathrm{~h}: n=12,8 \mathrm{~h}$ : $n=10,16 \mathrm{~h}: n=6,24 \mathrm{~h}$ fasted: $n=8$ ) mice fed ad libitum or fasted for 4, 8, 16 , or $24 \mathrm{~h}$. Gene expression was normalized to the housekeeping gene ACT $\beta$ and presented as relative expression compare to the lean-fed group. Letters that differ indicate differences within group $(a, b, c$ Lean, $x, y, z$ Obese), $P<0.01 ; * \star * *, * \star *, * *, *$ indicates when obese differs from

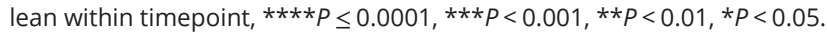
Bars indicate means \pm S.E.M.
Phosphorylation levels of (A, B and C) Ser133 in CREB, Ser63 in ATF-1, and total CREB protein, as and total AKT protein in livers of lean (fasted: $n=6$, re-fed: $n=8$ ) and diet-induced obese (fasted: for $2 \mathrm{~h}$ after a $16 \mathrm{~h}$ fast. (A and D) Representative quantification normalized to Histone H3. F, fasted; $\mathrm{RF}$, re-fed; $* P<0.05, * \star * \star p \leq 0.0001$, NS, not significant. Bars indicate means \pm S.E.M. 
A Pancreatic Glucagon Secretion
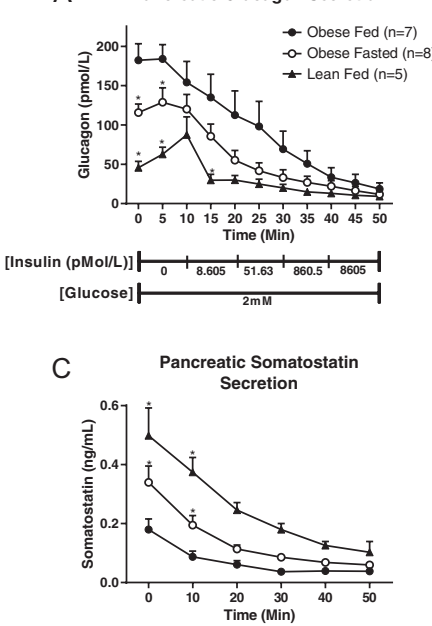

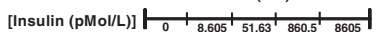
[Glucose]
B Pancreatic Glucagon Secretion

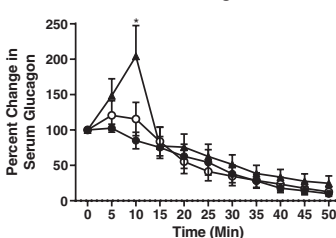

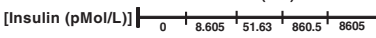

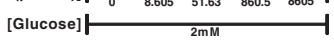

D Pancreatic Somatostatin

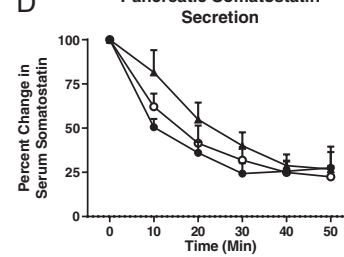

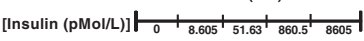
[Glucose]

Figure 7

Pancreatic secretion of (A) glucagon ( $\mathrm{pmol} / \mathrm{L})$, (B) glucagon (\% change from baseline), (C) somatostatin ( $\mathrm{ng} / \mathrm{mL})$, and $(D)$ somatostatin (\% change from baseline) in response to insulin perfusion in lean-fed $(n=5)$, obese fed $(n=7)$, and obese $16 \mathrm{~h}$ fasted $(n=8)$ mice. *Differs from fed obese, within timepoint $P<0.05$. Values are means \pm S.E.M.

fasted lean and diet-induced obese mice. Similar to our studies, they reported that in obese mice fed serum glucagon concentrations were 66\% higher than fasted serum glucagon concentrations, while in lean mice glucagon increased with fasting (Singh et al. 2007). Unfortunately, their results might have been confounded because of the use of different methods to assess plasma glucagon concentration in the fed and fasted states; they used an ELISA to assess glucagon in fasted samples and an RIA to determine glucagon in fed samples. Lavine et al. showed that liver cAMP concentrations decreased with fasting in the ob/ob mouse, but increased in wildtype controls. The authors concluded that the cause of such a paradoxical metabolic response to fasting is unknown

(Lavine et al. 1975). Our findings support the possibility that the decline in hepatic cAMP with fasting in the ob/ob mouse model was due to a decreased glucagon stimulation.

Although it is difficult to compare a fast in a human to that of a mouse, a 24-h food deprivation in a mouse may be more appropriately considered a starvation model rather than a fast. In fact, a 5-6h fast in a mouse may be more comparable to an overnight 12-h fast in humans (Andrikopoulos et al. 2008, Ayala et al. 2010, Jensen et al. 2013). Thus, to examine the effects of extended fasting on glucagon homeostasis in the obese T2DM human, a 72-h fast would likely be required to make comparisons in humans to our long-term fasting data in the mouse. In healthy people, plasma glucagon increases after a 72-h fast (Aguilar-Parada et al. 1969, Nair et al. 1987, Beer et al. 1989, Boyle et al. 1989, Hojlund et al. 2001), which is equivalent to a 16-24h fast in mice (Andrikopoulos et al. 2008, Ayala et al. 2010, Jensen et al. 2013). Yet, glucagon does not increase after a 12-h fast in healthy people (Hojlund et al. 2001, Nuttall et al. 2015), equivalent to a 6-h fast in mice (Andrikopoulos et al. 2008, Ayala et al. 2010, Jensen et al. 2013). Marliss et al. (1970) examined circulating glucagon in seven people with obesity over various intervals of a prolonged fast. Plasma glucagon rose 3 days after initiation of the fast, followed by a gradual return toward basal levels after 5, 14, and 42 days of fasting. The results of this study suggest that, unlike obese mice, obese humans respond to a short-term fast with an increase in circulating glucagon. However, glucagon values on days 1 and 2 of the fast in the study of Marliss et al. were not reported; thus, it is possible that a decline in glucagon during short-term fasting could have been missed. In concert with previous studies (Muller et al. 1970, Knop et al. 2007), we show that people with obesity do not suppress plasma glucagon in response to a meal.
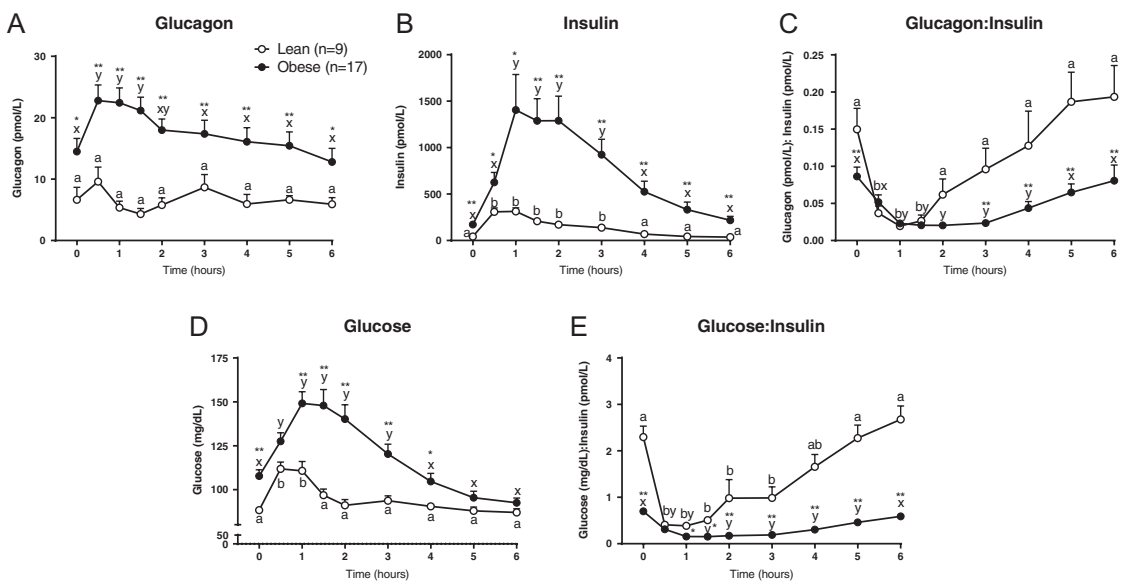

Figure 8

Plasma concentrations of (A) glucagon, (B) insulin, (C) glucagon: insulin ratio, (D) glucose, and (E) glucose: insulin ratio before (time 0 ) and for $6 \mathrm{~h}$ after ingesting a mixed meal consumed over 30 min in lean $(n=9)$ and obese $(n=17)$ participants. Letters that differ indicate differences within group (a,bLean, $x, y$ Obese) in response to the meal, $P<0.05$; **, * indicates when obese differs from lean within timepoint, $\star * P<0.01, * P<0.05$. Values are means \pm S.E.M. 
In fact, we observed a robust increase in glucagon immediately following a mixed meal. Similarly, we show that $2 \mathrm{~h}$ of re-feeding in the diet-induced obese mouse completely restores fed state hyperglucagonemia after a fasting-induced decrease in glucagon. Varying the macronutrient composition of a meal can lead to differential glucagon responses in both normal-weight people and people with obesity (Muller et al. 1970, Knop et al. 2007). Here, we have examined the impact of mixed meal feeding on the glucagon response in people with and without obesity. Future studies are needed to investigate the impact of acute and chronic diet macronutrient composition on meal-induced changes in glucagon.

The serum or plasma glucagon:insulin ratio is a better determinant of metabolic regulation than glucagon or insulin alone (Unger 1971, Parrilla et al. 1974). Moreover the peripheral glucagon:insulin ratio provides a reliable index of the ratio in the portal vein (Felig et al. 1974). Normally the glucagon:insulin ratio increases with fasting and starvation (Unger 1971), leading to an increase in hepatic intracellular concentrations of cAMP and downstream signaling (Seitz et al. 1977, Mutel et al. 2011). In contrast, re-feeding normally causes a decrease in the glucagon:insulin ratio. The predominant insulin signal decreases cAMP by activating phosphodiesterase (Benelli et al. 1986). In opposition, glucagon activates cAMP (Jelinek et al. 1993), which activates glycogenolysis and the expression of genes involved in gluconeogenesis and fatty acid $\beta$-oxidation (Koo et al. 2005, Zhang et al. 2005). We show that obesity dysregulates fasting-induced changes in circulating glucagon, the glucagon:insulin ratio, and the downstream effects of glucagon signaling at the liver, including cAMP and the concomitant phosphorylation of ATF-1 (Rehfuss et al. 1991, Sun et al. 1996), and mRNA expression of cAMP-regulated genes (Zhang et al. 2005). The static glucagon:insulin ratio in obesity during fasting may contribute to the impairments in glucose homeostasis observed in obesity. Obese mice do not respond to a fast with changes in cAMP or expression of hepatic genes that regulate gluconeogenesis, which may explain why hepatic gluconeogenesis and glucose output, which is elevated in the fed state in obesity, does not change in response to a fast. In line with this hypothesis, Belfiore et al. showed that the glucose 6 phosphatase: glucokinsae and fructose1,6-diphosphatase: phosphofructokinase ratios increase in response to a $48 \mathrm{~h}$ fast in lean mice, but do not change with fasting in obese, hyperglycemic mice (Belfiore et al. 1987).

The mechanism responsible for hyperglucagonemia in obesity and T2DM is not well understood. Insulin normally acts in a paracrine fashion to decrease glucagon secretion (Maruyama et al. 1984, Kawamori et al. 2009). Thus, it is possible that obesity-induced $\alpha$-cell IR (Larsson \& Ahren 2000, Knop et al. 2007, Bagger et al. 2014) contributes to hyperglucagonemia. Our studies in the obese mouse demonstrate that fasting decreases the hyperglucagonemia associated with obesity. Using our pancreatic perfusion model, we established that decreasing perfusate glucose from $5.5 \mathrm{mM}$ (equilibrium period) to $2 \mathrm{mM}$ increased glucagon secretion in lean, but not obese mice. This supports our in vivo observation that fasting increases glucagon secretion in lean but not obese mice. We subsequently sought to determine how fasting affected insulin-mediated suppression of $\alpha$-cell glucagon secretion. Our perfusion experiments showed that the decrease in circulating serum glucagon with fasting occurs in the obese mouse as a direct result of a decrease in pancreatic glucagon secretion, obese mice released more glucagon than lean mice, and that neither obesity nor fasting altered insulin inhibition of glucagon secretion. These experiments suggest that mechanisms other than impairment in $\alpha$-cell insulin sensing (Unger et al. 1972, Ipp 2000) cause the dysregulation in glucagon secretion associated with hyperinsulinemia and IR in obesity.

Somatostatin, secreted by pancreatic $\delta$-cells, also exerts a paracrine inhibitory action on $\alpha$-cell glucagon secretion (Hauge-Evans et al. 2009, Cheng-Xue et al. 2013, Elliott et al. 2015). Thus, we hypothesized that somatostatin secretion may be differentially affected by fasting in obese mice. Our results demonstrate that pancreatic somatostatin secretion from obese mice fasted for $16 \mathrm{~h}$ is greater than that of fed obese mice. Moreover, in the fed state, pancreata from lean-fed mice secrete more somatostatin than those of obese mice. These results are consistent with an increased inhibitory signal from somatostatin at the $\alpha$-cell, which could explain the fastinduced decrease in glucagon observed in obese mice.

Glucagon not only regulates glucose homeostasis, but also energy homeostasis. Glucagon increases energy expenditure in humans (Salem et al. 2016), non-human primates, and mice (Elvert et al. 2018). In fact, glucagon receptor agonists combined with glucagon-like peptide 1 receptor agonists increase energy expenditure and induce weight loss (Henderson et al. 2016, Elvert et al. 2018). Thus, fasting-induced decreases in glucagon secretion in people with obesity and the resulting alterations in the glucagon:insulin ratio could impede calorie-restrictive approaches to weight loss. Thus, future studies aimed at understanding the impact of fastinginduced changes in glucagon on energy expenditure in obesity are needed. 


\section{Conclusion}

Fasting in the diet-induced obese mouse induces a progressive decrease in glucagon secretion. Further, in both obese mice and humans, consuming a meal induces a rise in glucagon. We established that in mice this was a result of altered pancreatic glucagon release. This dysregulation of glucagon in obesity results in a more static glucagon:insulin ratio in obese than in normalweight humans and mice. Future studies are needed to assess the potential importance of alterations in the circulating glucagon:insulin ratio on metabolic function in people with obesity.

\section{Declaration of interest}

The authors declare that there is no conflict of interest that could be perceived as prejudicing the impartiality of the research reported.

\section{Funding}

Preclinical studies were supported by grants from the National Institutes of Health grants K99-AG055649, F32-DK107058 ( H S); R01-DK55758, R01-DK099110 and P01-DK088761-01, JDRF Grant 2SRA2016149QR and an unrestricted grant from the Novo Nordisk Research Foundation (P E S). Clinical studies were supported by National Institutes of Health grants DK56341, DK20579 and RR024992, and grants from Janssen R\&D and the Pershing Square Foundation (S K).

\section{Author contribution statement}

J H S, P E S, and R H U designed the mouse studies. G H S and S K designed and conducted the human clinical studies. J H S performed animal studies and data analysis. S C performed perfusion studies. J H S, P E S, and S K wrote the manuscript. All authors edited the manuscript and approved the final version. S K and P E S are the guarantors of the study.

\section{Prior presentation}

Parts of this study were presented in abstract form at the 78th Scientific Sessions of the American Diabetes Association, Orlando, FL, June 22-26, 2018.

\section{References}

Aguilar-Parada E, Eisentraut AM \& Unger RH 1969 Effects of starvation on plasma pancreatic glucagon in normal man. Diabetes 18 717-723. (https://doi.org/10.2337/diab.18.11.717)

Andrikopoulos S, Blair AR, Deluca N, Fam BC \& Proietto J 2008 Evaluating the glucose tolerance test in mice. American Journal of Physiology: Endocrinology and Metabolism 295 E1323-E1332. (https:// doi.org/10.1152/ajpendo.90617.2008)

Ayala JE, Samuel VT, Morton GJ, Obici S, Croniger CM, Shulman GI, Wasserman DH, Mcguinness OP \& NIH Mouse Metabolic
Phenotyping Center Consortium 2010 Standard operating procedures for describing and performing metabolic tests of glucose homeostasis in mice. Disease Models and Mechanisms 3 525-534. (https://doi. org/10.1242/dmm.006239)

Bagger JI, Knop FK, Lund A, Holst JJ \& Vilsboll T 2014 Glucagon responses to increasing oral loads of glucose and corresponding isoglycaemic intravenous glucose infusions in patients with type 2 diabetes and healthy individuals. Diabetologia 57 1720-1725. (https:// doi.org/10.1007/s00125-014-3264-2)

Baron AD, Schaeffer L, Shragg P \& Kolterman OG 1987 Role of hyperglucagonemia in maintenance of increased rates of hepatic glucose output in type II diabetics. Diabetes 36 274-283. (https://doi org/10.2337/diab.36.3.274)

Beer SF, Bircham PM, Bloom SR, Clark PM, Hales CN, Hughes CM, Jones CT, Marsh DR, Raggatt PR \& Findlay AL 1989 The effect of a 72-h fast on plasma levels of pituitary, adrenal, thyroid, pancreatic and gastrointestinal hormones in healthy men and women. Journal of Endocrinology 120 337-350. (https://doi.org/10.1677/ joe.0.1200337)

Belfiore F, Iannello S, Rabuazzo AM \& Campione R 1987 Metabolic effects of short-term fasting in obese hyperglycaemic humans and mice. International Journal of Obesity 11 631-640.

Benelli C, Desbuquois B \& De Galle B 1986 Acute in vivo stimulation of low-Km cyclic AMP phosphodiesterase activity by insulin in rat-liver Golgi fractions. European Journal of Biochemistry 156 211-220. (https:// doi.org/10.1111/j.1432-1033.1986.tb09570.x)

Boyle PJ, Shah SD \& Cryer PE 1989 Insulin, glucagon, and catecholamines in prevention of hypoglycemia during fasting. American Journal of Physiology 256 E651-E661. (https://doi. org/10.1152/ajpendo.1989.256.5.E651)

Cheng-Xue R, Gomez-Ruiz A, Antoine N, Noel LA, Chae HY, Ravier MA, Chimienti F, Schuit FC \& Gilon P 2013 Tolbutamide controls glucagon release from mouse islets differently than glucose: involvement of K(ATP) channels from both alpha-cells and delta-cells. Diabetes 62 1612-1622. (https://doi.org/10.2337/db12-0347)

Elliott AD, Ustione A \& Piston DW 2015 Somatostatin and insulin mediate glucose-inhibited glucagon secretion in the pancreatic alphacell by lowering cAMP. American Journal of Physiology: Endocrinology and Metabolism 308 E130-E143. (https://doi.org/10.1152/ ajpendo.00344.2014)

Elvert R, Herling AW, Bossart M, Weiss T, Zhang B, Wenski P, Wandschneider J, Kleutsch S, Butty U, Kannt A, et al. 2018 Running on mixed fuel-dual agonistic approach of GLP-1 and GCG receptors leads to beneficial impact on body weight and blood glucose control: a comparative study between mice and non-human primates. Diabetes, Obesity and Metabolism 20 1836-1851. (https://doi. org/10.1111/dom.13212)

Felig P, Gusberg R, Hendler R, Gump FE, Kinney JM \& Mulrow PJ 1974 Concentrations of glucagon and the insulin:glucagon ratio in the portal and peripheral circulation. Proceedings of the Society for Experimental Biology and Medicine 147 88-90. (https://doi. org/10.3181/00379727-147-38286)

Glinsmann WH \& Mortimore GE 1968 Influence of glucagon and $3^{\prime}, 5^{\prime}$-AMP on insulin responsiveness of the perfused rat liver. American Journal of Physiology 215 553-559. (https://doi.org/10.1152/ ajplegacy.1968.215.3.553)

Guerrero-Romero F \& Rodriguez-Moran M 2001 Glucose intolerance is predicted by the high fasting insulin-to-glucose ratio. Diabetes and Metabolism 27 117-121.

Hare KJ, Vilsboll T, Asmar M, Deacon CF, Knop FK \& Holst JJ 2010 The glucagonostatic and insulinotropic effects of glucagon-like peptide 1 contribute equally to its glucose-lowering action. Diabetes $\mathbf{5 9}$ 1765-1770. (https://doi.org/10.2337/db09-1414)

Hauge-Evans AC, King AJ, Carmignac D, Richardson CC, Robinson IC, Low MJ, Christie MR, Persaud SJ \& Jones PM 2009 Somatostatin secreted by islet delta-cells fulfills multiple roles as a paracrine https://joe.bioscientifica.com https://doi.org/10.1530/JOE-19-0201 (c) 2019 Society for Endocrinology Published by Bioscientifica Ltd. Printed in Great Britain 
regulator of islet function. Diabetes 58 403-411. (https://doi. org/10.2337/db08-0792)

Henderson SJ, Konkar A, Hornigold DC, Trevaskis JL, Jackson R, Fritsch Fredin M, Jansson-Lofmark R, Naylor J, Rossi A, Bednarek MA, et al. 2016 Robust anti-obesity and metabolic effects of a dual GLP-1/ glucagon receptor peptide agonist in rodents and non-human primates. Diabetes, Obesity and Metabolism 18 1176-1190. (https://doi. org/10.1111/dom.12735)

Hojlund K, Wildner-Christensen M, Eshoj O, Skjaerbaek C, Holst JJ, Koldkjaer O, Moller Jensen D \& Beck-Nielsen H 2001 Reference intervals for glucose, beta-cell polypeptides, and counterregulatory factors during prolonged fasting. American Journal of Physiology: Endocrinology and Metabolism 280 E50-E58. (https://doi.org/10.1152/ ajpendo.2001.280.1.E50)

Ipp E 2000 Impaired glucose tolerance: the irrepressible alpha-cell? Diabetes Care 23 569-570. (https://doi.org/10.2337/diacare.23.5.569)

Jelinek LJ, Lok S, Rosenberg GB, Smith RA, Grant FJ, Biggs S, Bensch PA, Kuijper JL, Sheppard PO \& Sprecher CA 1993 Expression cloning and signaling properties of the rat glucagon receptor. Science 259 1614-1616. (https://doi.org/10.1126/science.8384375)

Jensen TL, Kiersgaard MK, Sorensen DB \& Mikkelsen LF 2013 Fasting of mice: a review. Laboratory Animals 47 225-240. (https://doi. org/10.1177/0023677213501659)

Jewell JL, Fu V, Hong AW, Yu FX, Meng D, Melick CH, Wang H, Lam WM, Yuan HX, Taylor SS, et al. 2019 GPCR signaling inhibits mTORC1 via PKA phosphorylation of raptor. eLife $\mathbf{8}$ e43038. (https://doi. org/10.7554/eLife.43038)

Kawamori D, Kurpad AJ, Hu J, Liew CW, Shih JL, Ford EL, Herrera PL, Polonsky KS, Mcguinness OP \& Kulkarni RN 2009 Insulin signaling in alpha cells modulates glucagon secretion in vivo. Cell Metabolism 9 350-361. (https://doi.org/10.1016/j.cmet.2009.02.007)

Kazda CM, Ding Y, Kelly RP, Garhyan P, Shi C, Lim CN, Fu H, Watson DE, Lewin AJ, Landschulz WH, et al. 2016 Evaluation of efficacy and safety of the glucagon receptor antagonist LY2409021 in patients with type 2 diabetes: 12- and 24-week phase 2 studies. Diabetes Care 39 1241-1249. (https://doi.org/10.2337/dc15-1643)

Knop FK, Vilsboll T, Madsbad S, Holst JJ \& Krarup T 2007 Inappropriate suppression of glucagon during OGTT but not during isoglycaemic i.v. glucose infusion contributes to the reduced incretin effect in type 2 diabetes mellitus. Diabetologia 50 797-805. (https://doi. org/10.1007/s00125-006-0566-z)

Koo SH, Flechner L, Qi L, Zhang X, Screaton RA, Jeffries S, Hedrick S, Xu W, Boussouar F, Brindle P, et al. 2005 The CREB coactivator TORC2 is a key regulator of fasting glucose metabolism. Nature $\mathbf{4 3 7}$ 1109-1111. (https://doi.org/10.1038/nature03967)

Kostic A, King TA, Yang F, Chan KC, Yancopoulos GD, Gromada J \& Harp JB 2018 A first-in-human pharmacodynamic and pharmacokinetic study of a fully human anti-glucagon receptor monoclonal antibody in normal healthy volunteers. Diabetes, Obesity and Metabolism 20 283-291. (https://doi.org/10.1111/dom.13075)

Krebs S, Fischaleck M \& Blum H 2009 A simple and loss-free method to remove Trizol contaminations from minute RNA samples. Analytical Biochemistry 387 136-138. (https://doi.org/10.1016/j.ab.2008.12.020)

Larsson H \& Ahren B 2000 Islet dysfunction in insulin resistance involves impaired insulin secretion and increased glucagon secretion in postmenopausal women with impaired glucose tolerance. Diabetes Care 23 650-657. (https://doi.org/10.2337/diacare.23.5.650)

Lavine RL, Voyles N, Perrino PV \& Recant L 1975 The effect of fasting on tissue cyclic cAMP and plasma glucagon in the obese hyperglycemic mouse. Endocrinology 97 615-620. (https://doi. org/10.1210/endo-97-3-615)

Lee Y, Wang MY, Du XQ, Charron MJ \& Unger RH 2011 Glucagon receptor knockout prevents insulin-deficient type 1 diabetes in mice. Diabetes 60 391-397. (https://doi.org/10.2337/db10-0426)

Lee Y, Berglund ED, Yu X, Wang MY, Evans MR, Scherer PE, Holland WL, Charron MJ, Roth MG \& Unger RH 2014 Hyperglycemia in rodent models of type 2 diabetes requires insulin-resistant alpha cells. PNAS 111 13217-13222. (https://doi.org/10.1073/pnas.1409638111)

Legro RS, Finegood D \& Dunaif A 1998 A fasting glucose to insulin ratio is a useful measure of insulin sensitivity in women with polycystic ovary syndrome. Journal of Clinical Endocrinology and Metabolism 83 2694-2698. (https://doi.org/10.1210/jcem.83.8.5054)

Livak KJ \& Schmittgen TD 2001 Analysis of relative gene expression data using real-time quantitative PCR and the 2(-delta delta C(T)) method. Methods 25 402-408. (https://doi.org/10.1006/meth.2001.1262)

Lo S, Russell JC \& Taylor AW 1970 Determination of glycogen in small tissue samples. Journal of Applied Physiology 28 234-236. (https://doi. org/10.1152/jappl.1970.28.2.234)

Lu M, Wan M, Leavens KF, Chu Q, Monks BR, Fernandez S, Ahima RS, Ueki K, Kahn CR \& Birnbaum MJ 2012 Insulin regulates liver metabolism in vivo in the absence of hepatic Akt and FoxO1. Nature Medicine 18 388-395. (https://doi.org/10.1038/nm.2686)

Mackrell DJ \& Sokal JE 1969 Antagonism between the effects of insulin and glucagon on the isolated liver. Diabetes 18 724-732. (https://doi. org/10.2337/diab.18.11.724)

Marliss EB, Aoki TT, Unger RH, Soeldner JS \& Cahill GF 1970 Glucagon levels and metabolic effects in fasting man. Journal of Clinical Investigation 49 2256-2270. (https://doi.org/10.1172/JCI106445)

Maruyama H, Hisatomi A, Orci L, Grodsky GM \& Unger RH 1984 Insulin within islets is a physiologic glucagon release inhibitor. Journal of Clinical Investigation 74 2296-2299. (https://doi.org/10.1172/JCI111658)

Mifflin MD, St Jeor ST, Hill LA, Scott BJ, Daugherty SA \& Koh YO 1990 A new predictive equation for resting energy expenditure in healthy individuals. American Journal of Clinical Nutrition 51 241-247. (https:// doi.org/10.1093/ajcn/51.2.241)

Muller WA, Faloona GR, Aguilar-Parada E \& Unger RH 1970 Abnormal alpha-cell function in diabetes. Response to carbohydrate and protein ingestion. New England Journal of Medicine 283 109-115. (https://doi. org/10.1056/NEJM197007162830301)

Mutel E, Gautier-Stein A, Abdul-Wahed A, Amigo-Correig M, Zitoun C, Stefanutti A, Houberdon I, Tourette JA, Mithieux G \& Rajas F 2011 Control of blood glucose in the absence of hepatic glucose production during prolonged fasting in mice: induction of renal and intestinal gluconeogenesis by glucagon. Diabetes $603121-3131$. (https://doi. org/10.2337/db11-0571)

Nair KS, Woolf PD, Welle SL \& Matthews DE 1987 Leucine, glucose, and energy metabolism after 3 days of fasting in healthy human subjects. American Journal of Clinical Nutrition 46 557-562. (https://doi. org/10.1093/ajcn/46.4.557)

Nauck MA, Kleine N, Orskov C, Holst JJ, Willms B \& Creutzfeldt W 1993 Normalization of fasting hyperglycaemia by exogenous glucagonlike peptide 1 (7-36 amide) in type 2 (non-insulin-dependent) diabetic patients. Diabetologia 36 741-744. (https://doi.org/10.1007/ bf00401145)

Nuttall FQ, Almokayyad RM \& Gannon MC 2015 Comparison of a carbohydrate-free diet vs. fasting on plasma glucose, insulin and glucagon in type 2 diabetes. Metabolism: Clinical and Experimental 64 253-262. (https://doi.org/10.1016/j.metabol.2014.10.004)

Parrilla R, Goodman MN \& Toews CJ 1974 Effect of glucagon: insulin ratios on hepatic metabolism. Diabetes 23 725-731. (https://doi. org/10.2337/diab.23.9.725)

Ramakers C, Ruijter JM, Deprez RH \& Moorman AF 2003 Assumption-free analysis of quantitative real-time polymerase chain reaction (PCR) data. Neuroscience Letters 339 62-66. (https://doi.org/10.1016/s03043940(02)01423-4)

Rehfuss RP, Walton KM, Loriaux MM \& Goodman RH 1991 The cAMPregulated enhancer-binding protein ATF-1 activates transcription in response to cAMP-dependent protein kinase A. Journal of Biological Chemistry 266 18431-18434.

Rivero-Gutierrez B, Haller A, Holland J, Yates E, Khrisna R, Habegger K, Dimarchi R, D'Alessio D \& Perez-Tilve D 2018 Deletion of the glucagon receptor gene before and after experimental diabetes reveals https://joe.bioscientifica.com

https://doi.org/10.1530/JOE-19-0201 (c) 2019 Society for Endocrinology Published by Bioscientifica Ltd. Printed in Great Britain 
differential protection from hyperglycemia. Molecular Metabolism 17 28-38. (https://doi.org/10.1016/j.molmet.2018.07.012)

Salem V, Izzi-Engbeaya C, Coello C, Thomas DB, Chambers ES, Comninos AN, Buckley A, Win Z, Al-Nahhas A, Rabiner EA, et al. 2016 Glucagon increases energy expenditure independently of brown adipose tissue activation in humans. Diabetes, Obesity and Metabolism 18 72-81. (https://doi.org/10.1111/dom.12585)

Seitz HJ, Muller MJ, Krone W \& Tarnowski W 1977 Coordinate control of intermediary metabolism in rat liver by the insulin/glucagon ratio during starvation and after glucose refeeding. Regulatory significance of long-chain acyl-CoA and cyclic AMP. Archives of Biochemistry and Biophysics 183 647-663. (https://doi.org/10.1016/00039861(77)90399-x)

Shah P, Vella A, Basu A, Basu R, Schwenk WF \& Rizza RA 2000 Lack of suppression of glucagon contributes to postprandial hyperglycemia in subjects with type 2 diabetes mellitus. Journal of Clinical Endocrinology and Metabolism 85 4053-4059. (https://doi.org/10.1210/ jcem.85.11.6993)

Singh V, Grotzinger C, Nowak KW, Zacharias S, Goncz E, Pless G, Sauer IM, Eichhorn I, Pfeiffer-Guglielmi B, Hamprecht B, et al. 2007 Somatostatin receptor subtype-2-deficient mice with diet-induced obesity have hyperglycemia, nonfasting hyperglucagonemia, and decreased hepatic glycogen deposition. Endocrinology 148 3887-3899. (https://doi.org/10.1210/en.2006-1659)

Sun P, Lou L \& Maurer RA 1996 Regulation of activating transcription factor- 1 and the cAMP response element-binding protein by $\mathrm{Ca} 2+/$ calmodulin-dependent protein kinases type I, II, and IV. Journal of Biological Chemistry 271 3066-3073. (https://doi.org/10.1074/ jbc.271.6.3066)

Townsend LK, Medak KD, Peppler WT, Meers GM, Rector RS, Leblanc PJ \& Wright DC 2019 High-saturated-fat diet-induced obesity causes hepatic interleukin-6 resistance via endoplasmic reticulum stress. Journal of Lipid Research 60 1236-1249. (https://doi.org/10.1194/jlr M092510)

Unger RH 1971 Glucagon and the insulin: glucagon ratio in diabetes and other catabolic illnesses. Diabetes 20 834-838. (https://doi. org/10.2337/diab.20.12.834)

Unger RH \& Orci L 1975 The essential role of glucagon in the pathogenesis of diabetes mellitus. Lancet 1 14-16. (https://doi. org/10.1016/s0140-6736(75)92375-2)

Unger RH, Madison LL \& Muller WA 1972 Abnormal alpha cell function in diabetics response to insulin. Diabetes 21 301-307. (https://doi. org/10.2337/diab.21.5.301)

Vajda EG, Logan D, Lasseter K, Armas D, Plotkin DJ, Pipkin JD, Li YX, Zhou R, Klein D, Wei X, et al. 2017 Pharmacokinetics and pharmacodynamics of single and multiple doses of the glucagon receptor antagonist LGD-6972 in healthy subjects and subjects with type 2 diabetes mellitus. Diabetes, Obesity and Metabolism 19 24-32. (https://doi.org/10.1111/dom.12752)

Vuguin P, Saenger P \& Dimartino-Nardi J 2001 Fasting glucose insulin ratio: a useful measure of insulin resistance in girls with premature adrenarche. Journal of Clinical Endocrinology and Metabolism 86 4618-4621. (https://doi.org/10.1210/jcem.86.10.7956)

Wargent ET 2009 The measurement of insulin secretion using pancreas perfusion in the rodent. Methods in Molecular Biology 560 203-219. (https://doi.org/10.1007/978-1-59745-448-3_14)

Zhang X, Odom DT, Koo SH, Conkright MD, Canettieri G, Best J, Chen H, Jenner R, Herbolsheimer E, Jacobsen E, et al. 2005 Genome-wide analysis of cAMP-response element binding protein occupancy, phosphorylation, and target gene activation in human tissues. PNAS 102 4459-4464. (https://doi.org/10.1073/ pnas.0501076102)

Received in final form 8 August 2019

Accepted 27 August 2019

Accepted Preprint published online 27 August 2019
(C) 2019 Society for Endocrinology Published by Bioscientifica Ltd. 